\title{
Ciclopirox inhibits cancer cell proliferation by suppression of Cdc25A
}

\author{
Tao Shen ${ }^{1,2}$, Chaowei Shang ${ }^{1,2}$, Hongyu Zhou ${ }^{1}$, Yan Luo ${ }^{1,3}$, Mansoureh Barzegar ${ }^{1}$, \\ Yoshinobu Odaka ${ }^{1,2}$, Yang Wu ${ }^{1,3}$, Shile Huang ${ }^{1,2}$ \\ ${ }^{1}$ Department of Biochemistry and Molecular Biology, Louisiana State University Health Sciences Center, Shreveport, LA, USA \\ ${ }^{2}$ Feist-Weiller Cancer Center, Louisiana State University Health Sciences Center, Shreveport, LA, USA \\ ${ }^{3}$ State Key Laboratory of Biotherapy / Collaborative Innovation Center of Biotherapy, West China Hospital, Sichuan University, \\ Chengdu, Sichuan, P.R. China \\ Correspondence to: Shile Huang, email: shuan $1 @$ Isuhsc.edu \\ Keywords: Ciclopirox, Cdc25A, cyclin dependent kinase, cell cycle, cell proliferation \\ $\begin{array}{lll}\text { Received: April 10, } 2017 & \text { Accepted: May 21, } 2017 & \text { Published: May 22, } 2017\end{array}$
}

Copyright: Shen et al. This is an open-access article distributed under the terms of the Creative Commons Attribution License (CC-BY), which permits unrestricted use, distribution, and reproduction in any medium, provided the original author and source are credited.

\section{ABSTRACT}

Ciclopirox olamine (CPX), an off-patent fungicide, has recently been identified as a novel anticancer agent. However, the molecular mechanism underlying its anticancer action remains to be elucidated. Here we show that CPX inhibits cell proliferation in part by downregulating the protein level of Cdc25A in tumor cells. Our studies revealed that CPX did not significantly reduce Cdc25A mRNA level or Cdc25A protein synthesis, but remarkably promoted Cdc25A protein degradation. This resulted in inhibition of $\mathbf{G}_{1}$-cyclin dependent kinases (CDKs), as evidenced by increased inhibitory phosphorylation of $\mathbf{G}_{1}-$-CDKs. Since Cdc25A degradation is tightly related to its phosphorylation status, we further examined whether CPX alters Cdc25A phosphorylation. The results showed that CPX treatment increased the phosphorylation of Cdc25A (S76 and S82), but only Cdc25A-S82A mutant was resistant to CPX-induced degradation. Furthermore, ectopic expression of Cdc25AS82A partially conferred resistance to CPX inhibition of cell proliferation. Therefore, our findings indicate that CPX inhibits cell proliferation at least in part by promoting Cdc25A degradation.

\section{INTRODUCTION}

Ciclopirox olamine (CPX), a synthetic fungicide, has been used for the treatment of superficial fungal infections for over two decades [1]. Studies have shown that CPX not only possesses antimycotic and antibacterial activities [1], but also arrests cells in $G_{1}$ phase of the cell cycle in mammalian cells $[2,3]$. A 4-week oral administration of CPX at $30 \mathrm{mg} / \mathrm{kg}$ body weight or a 3-month administration of CPX at $10 \mathrm{mg} / \mathrm{kg}$ does not exhibit obvious toxicity in various experimental animals [4]. Serum concentrations $(\sim 10 \mu \mathrm{M})$ of CPX are achievable after repeated administration of CPX to rats and dogs, and are not toxic, suggesting favorable safety and pharmacokinetic profiles of CPX [5]. Recently, preclinical studies have revealed that CPX has potent anticancer activity in various cancer cell lines [6-16].
Also, a phase I clinical trial study has shown that oral administration of CPX at a dose of $40 \mathrm{mg} / \mathrm{m}^{2}$ once daily for 5 days is well tolerated in patients, and induces disease stabilization and/or hematologic improvement in $2 / 3$ patients with advanced hematologic malignancies [17]. It has been shown that CPX exerts its anticancer activity by inhibiting proliferation, and inducing cell death in tumor cells [6,7]. In addition, CPX can also inhibit angiogenesis and lymphangiogenesis $[18,19]$. Therefore, accumulating evidence suggests that CPX is a promising anticancer agent and may be repositioned for cancer therapy.

Despite the above exciting findings, the molecular mechanisms underlying the anticancer action of CPX are only at the beginning of investigation. It has been shown that CPX inhibits angiogenesis by blocking proline hydroxylation and maturation of collagen in human umbilical vein endothelial cells [18]. CPX inhibits 
lymphangiogenesis in an in vitro model (lymphatic endothelial cell tube formation) by suppressing vascular endothelial growth factor receptor 3 mediated extracellular signal-regulated protein kinases $1 / 2$ signaling pathway [19]. CPX induces cell death in leukemia and myeloma cells by inhibiting the iron-dependent enzyme ribonucleotide reductase [6] and $\mathrm{Wnt} / \beta$-catenin pathway [9]. CPX induces apoptosis in rhabdomyosarcoma and breast cancer cells by downregulating the protein levels of $\mathrm{Bcl}-\mathrm{xL}$ and survivin and increasing the cleavage of Bcl-2 [7]. CPX induces autophagy by inducing reactive oxygen species and activating c-Jun $\mathrm{N}$-terminal kinase cascade [14]. Of interest, CPX has been consistently found to inhibit cell proliferation by arresting cells in $\mathrm{G}_{1}$ phase of the cell cycle $[3,7,15]$, which is attributed to inhibition of cyclin dependent kinases (CDKs) [7]. Nevertheless, how CPX inhibits CDKs is not fully elucidated.

The activities of CDKs are precisely regulated by multiple events including phosphorylation, dephosphorylation and protein-protein interactions, among which, the removal of inhibitory phosphorylation on CDKs by cell division cycle 25 (Cdc25), a dual-specificity protein phosphatase, is crucial for the full activation of CDKs [20-23]. The Cdc25 family has three members: Cdc25A, Cdc25B, and Cdc25C. Although the catalytic domains of these phosphatases are well conserved, their regulatory domains, which decide their subcellular distribution and turnover, are greatly diverse [22, 23]. While Cdc25B and $\mathrm{Cdc} 25 \mathrm{C}$ promote $\mathrm{G}_{2} / \mathrm{M}$ progression by primarily dephosphorylating CDK1 at T14/Y15, two inhibitory phosphorylation sites [24, 25], Cdc25A plays a more extensive role in assisting both $\mathrm{G}_{1} / \mathrm{S}$ and $\mathrm{G}_{2} / \mathrm{M}$ progression by dephosphorylating CDK4 at Y17 [26], CDK6 at Y24 [27], as well as CDK2 and CDK1 at T14/ Y15 [28 29]. More importantly, overexpression of Cdc25A has been frequently observed in multiple types of tumors, which is correlated to the poor prognosis in cancer patients [22]. Hence, Cdc25A has emerged as a potential target for cancer therapy [22]. Recently, we have noticed that CPX inhibits CDKs, in part by downregulating the protein levels of cyclins (A, B1, D1 and E) and CDK2/4 [7]. Given that Cdc25A is a very important positive regulator of CDKs, we hypothesized that $\mathrm{Cdc} 25 \mathrm{~A}$ may play a critical role in CPX-induced inhibition of CDK or inhibition of cell proliferation.

Here, for the first time, we show that Cdc25A is involved in CPX-induced inhibition of CDK or inhibition of cell proliferation. Our results indicated that CPX induced the phosphorylation of $\mathrm{Cdc} 25 \mathrm{~A}$, which promoted protein degradation of $\mathrm{Cdc} 25 \mathrm{~A}$ in rhabdomyosarcoma (Rh30) and breast cancer (MDA-MB-231) cells. Downregulation of $\mathrm{Cdc} 25$ protein level consequently accumulated the inhibitory phosphorylation level on $\mathrm{G}_{1-}$ CDKs. The finding sheds new insights on the mechanism by which CPX inhibits CDKs related to cell proliferation.

\section{RESULTS}

\section{CPX inhibits cell proliferation in tumor cells}

To investigate the anti-proliferative effect of CPX on tumor cells, six human tumor cell lines, including Rh30 and RD rhabdomyosarcoma cells, MDA-MB-231 and MCF7 breast cancer cells, A549 lung cancer cells, and HT29 colon cancer cells, were employed. When these cells, grown under normal growth conditions, were exposed to CPX (0-20 $\mu \mathrm{M})$ for 6 days, CPX inhibited the cell proliferation in a concentration-dependent manner, with $\mathrm{IC}_{50}$ values ranging from 1.5 to $4.9 \mu \mathrm{M}$ (Figure 1A). The results support the notion that CPX is a potent anticancer agent.

As MDA-MB-231 and Rh30 are both p53 mutant $[30,31]$ and frequently used for cancer research, these two cell lines were selected for further experiments in this study. As detected by one solution assay, treatment with CPX for $48 \mathrm{~h}$ also inhibited proliferation of Rh30 and MDA-MB-231 cells in a concentration-dependent manner (Figure 1B). Of note, the 48-h growth inhibitory effect of CPX, particularly at higher concentrations $(>10 \mu \mathrm{M})$, was not as potent as that in the above 6-day growth inhibition assay (Figure 1A). This is consistent with our previous findings that treatment with higher concentrations of CPX $(10-20 \mu \mathrm{M})$ for $72 \mathrm{~h}$ or longer time not only inhibits cell proliferation, but also induces significant apoptosis in the tumor cells [7].

\section{CPX accumulates cells at $G_{1}$ phase of the cell cycle}

Our previous dose-response experiments have shown that treatment with CPX $(0-20 \mu \mathrm{M})$ for $24 \mathrm{~h}$ accumulates cells at $\mathrm{G}_{1} / \mathrm{G}_{0}$ phase in a concentrationdependent manner [7]. Since $5 \mu \mathrm{M}$ of CPX was able to inhibit cell proliferation significantly in both MDAMB-231 and Rh30 cells (Figure 1), this concentration was chosen for a time course analysis of the cell cycle, in order to determine whether CPX slows down cell cycle progression or arrests cells in $G_{1}$ phase. As illustrated in Figure 2, CPX induced accumulation of Rh30 cells at $\mathrm{G}_{1} /$ $\mathrm{G}_{0}$ phase in a time-dependent manner. Treatment with CPX $(5 \mu \mathrm{M})$ for $24 \mathrm{~h}$ was able to significantly increase the $\mathrm{G}_{1}$ population. Correspondingly, the percentages of the cells in $\mathrm{S}$ and $\mathrm{G}_{2} / \mathrm{M}$ phases decreased. By extending the treatment for up to $72 \mathrm{~h}$, which is longer than the doubling time (36 h) for Rh30 cell line [32], more cells were accumulated in $G_{1} / G_{0}$ phase, indicating that a $G_{1}$ arrest was induced. Similarly, 24-h treatment with $5 \mu \mathrm{M}$ of CPX also accumulated cells in $\mathrm{G}_{1}$ phase of the cell cycle in MDA-MB-231 cells (Supplementary Figure S1). 
CPX downregulates the expression of Cdc25A, resulting in increased inhibitory phosphorylation of $\mathrm{G}_{\mathbf{1}}-\mathrm{CDKs}$ in tumor cells

Both cyclin D1-CDK4/6 and cyclin E-CDK2 complexes are important for $\mathrm{G}_{1} \rightarrow$ S cell cycle progression $[20,21]$. Recently, we have observed that treatment with 5 $\mu \mathrm{M}$ of CPX for $24 \mathrm{~h}$ neither obviously downregulated the protein levels of cyclins $\mathrm{A} / \mathrm{B} 1$ and $\mathrm{CDK} 2$, nor apparently upregulated the protein levels of the CDK inhibitors $\mathrm{p} 21^{\mathrm{Cip} 1}$ and $\mathrm{p} 27^{\mathrm{Kip} 1}$, but only modestly decreased the protein
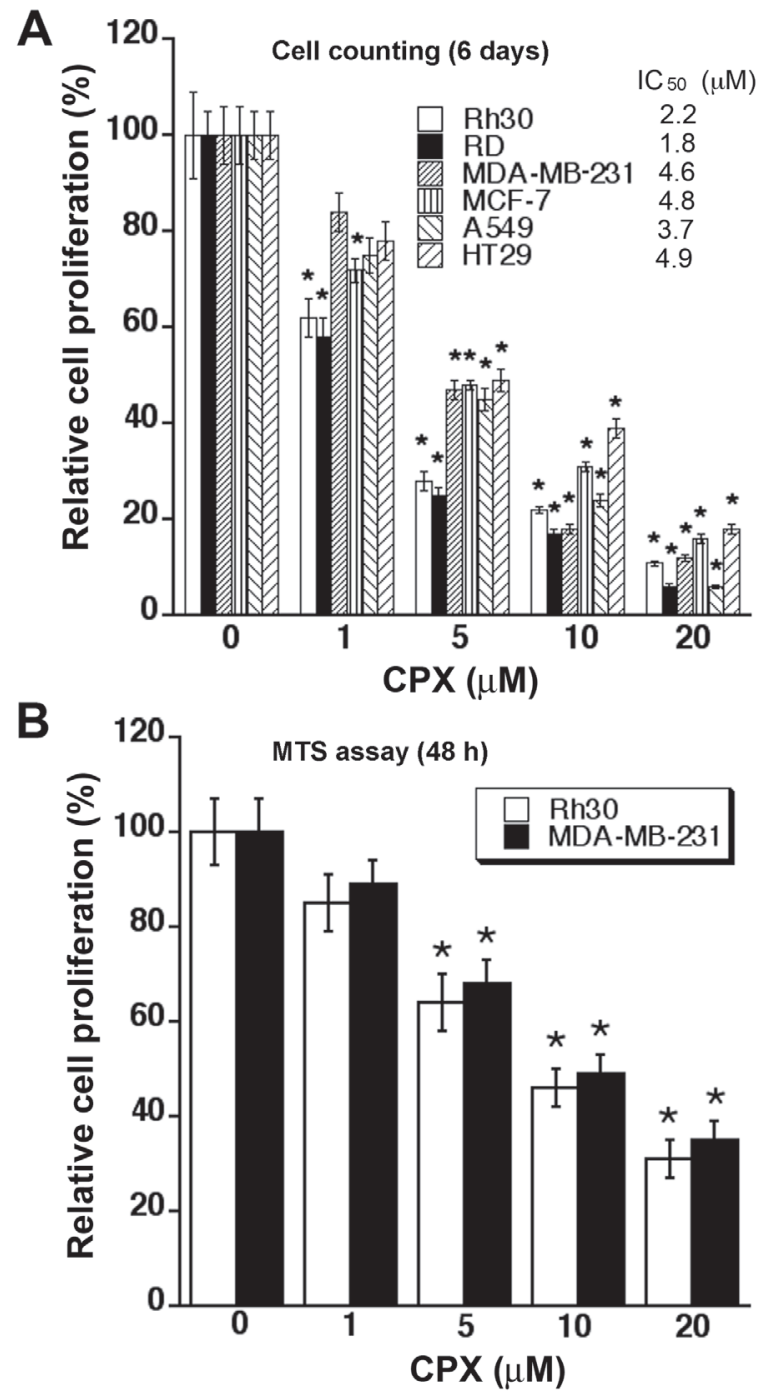

Figure 1: CPX inhibits cell proliferation in tumor cells. (A) Indicated cell lines, grown under normal conditions, were treated with $\mathrm{CPX}(0-20 \mu \mathrm{M})$ for 6 days, followed by cell counting. (B) MDA-MB-231 and Rh30 cells were treated with CPX (0-20 $\mu \mathrm{M})$ for $48 \mathrm{~h}$, followed by one solution cell proliferation assay. All data represent the means $\pm \mathrm{SE}(\mathrm{n}=3) . * P<0.05$. levels of cyclins D1/E and CDK4 [7]. Since Cdc25A is a positive regulator for $\mathrm{G}_{1}-\mathrm{CDKs}[22,23]$, we speculated that $5 \mu \mathrm{M}$ of CPX may induce the $\mathrm{G}_{1}$ arrest of the cells by decreasing Cdc25A level. To this end, MDA-MB-231 cells were treated with CPX $(0-20 \mu \mathrm{M})$ for $24 \mathrm{~h}$, followed by Western blot analysis. We found that treatment with CPX $(0-20 \mu \mathrm{M})$ for $24 \mathrm{~h}$ reduced the levels of Cdc25A in a concentration-dependent manner (Left panel, Figure 3A). Of interest, treatment with $\mathrm{CPX}(\geq 5 \mu \mathrm{M})$ for $24 \mathrm{~h}$ was able to dramatically reduce the level of Cdc25A in the cells. In contrast, the inhibitory effect of CPX on cyclin D1 expression was modest (Left panel, Figure 3A). Similar results were observed in Rh30 cells (Right panel, Figure 3A). Moreover, in A549 and HT29 cells, 24-h treatment with CPX did not obviously downregulate cyclin D1 protein level, but markedly reduced Cdc25A protein level in a concentration-dependent manner (Supplementary Figure S2). The results support our hypothesis that CPX downregulation of Cdc25A may play a critical role in inducing $\mathrm{G}_{1}$ cell cycle arrest.

Since studies have demonstrated that CDK2 and CDK4/6 have overlapped functions [20,21], it is necessary to inhibit both D1-CDK4/6 and E-CDK2 for completely arresting cells in $\mathrm{G}_{1}$ phase. Having observed that treatment with $5 \mu \mathrm{M}$ of CPX significantly induced $\mathrm{G}_{1}$ arrest (Figure 2) and remarkably downregulated the protein level of Cdc25A in tumor cells (Figure 3A), we reasoned that $\mathrm{CPX}$ at this concentration might inhibit the

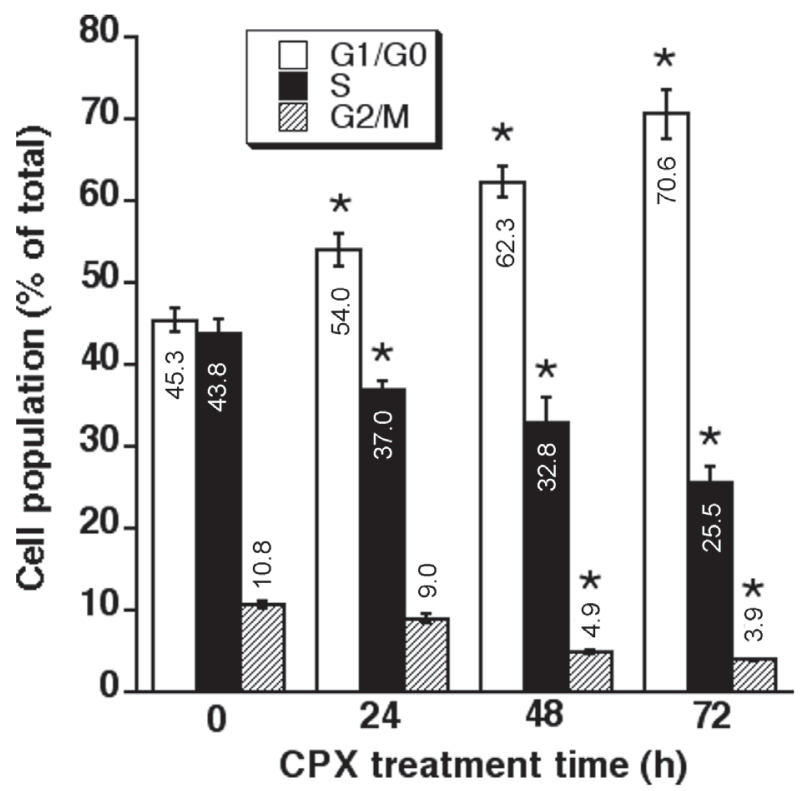

Figure 2: CPX induces accumulation of Rh30 cells at $G_{1}$ phase of the cell cycle in a time-dependent manner. Rh30 cells were exposed to CPX ( 0 and $5 \mu \mathrm{M})$ for 24,48 and $72 \mathrm{~h}$, respectively, followed by cell cycle analysis. All data represent the means $\pm \mathrm{SE}(\mathrm{n}=3)$. ${ }^{*} P<0.05$. 
activity of CDK2 by increasing the level of its inhibitory phosphorylation, leading to $\mathrm{G}_{1}$ arrest in the cells. For this, MDA-MB-231 cells were treated with CPX $(5 \mu \mathrm{M})$ for 0-24 h, followed by Western blot analysis. As predicted, treatment with CPX $(5 \mu \mathrm{M})$ reduced the protein level of Cdc25A in a time dependent manner. Concurrently, CPX increased the level of the inhibitory phosphorylation of CDK2 (Y15) in the cells (Left panel, Figure 3B), indicating inhibition of CDK2 activity. Similar data were observed in Rh30 cells (Right panel, Figure 3B). Since Cdc25A can dephosphorylate both CDK2 and CDK4/6 [22, 23], we also checked whether CPX induces the inhibitory phosphorylation of CDK6. As expected, treatment with CPX (5 $\mu \mathrm{M})$ also induced the inhibitory phosphorylation of CDK6 (Y24) in both MDA-MB-231 and Rh30 cells in a time dependent manner (Figure 3B). Collectively, the results indicate that CPX downregulation of $\mathrm{Cdc} 25 \mathrm{~A}$ protein level contributes to the inhibition of $\mathrm{G}_{1}-\mathrm{CDKs}$, resulting in the $\mathrm{G}_{1}$ cell cycle arrest.

\section{CPX downregulates Cdc25A expression by promoting Cdc25A protein degradation}

Regulation of Cdc25A protein level may occur at transcriptional, translational and/or posttranslational level $[22,23]$. To elucidate how CPX downregulates the protein level of Cdc25A, semi-quantitative RT-PCR was first employed to determine whether CPX reduces Cdc25A mRNA expression. As shown in Figure 4A, treatment with CPX $(2.5-20 \mu \mathrm{M})$ for $24 \mathrm{~h}$ slightly but not significantly reduced Cdc25A mRNA level in MDAMB-231 cells. Similar results were observed in Rh30 cells (Supplementary Figure S3A).

Next, ${ }^{35} \mathrm{~S}-\mathrm{Met} / \mathrm{Cys}$ labeling was used to determine whether CPX downregulates Cdc25A protein expression by decreasing Cdc25A protein synthesis. For this, MDAMB-231 were pretreated with CPX at 0-20 $\mu \mathrm{M}$ for $18 \mathrm{~h}$, and then pulsed with ${ }^{35} \mathrm{~S}-\mathrm{Met} / \mathrm{Cys} 6 \mathrm{~h}$ in the presence of CPX $(0-20 \mu \mathrm{M})$, followed by autoradiography. The results indicate that pretreatment with CPX at $2.5-20 \mu \mathrm{M}$ for $18 \mathrm{~h}$ did not obviously inhibit incorporation of ${ }^{35} \mathrm{~S}-\mathrm{Met} / \mathrm{Cys}$ into Cdc25A, compared with the control (Figure 4B). Similar results were observed in Rh30 cells (Supplementary Figure S3B).

To determine whether CPX downregulates Cdc25A protein expression by increasing its protein degradation, MDA-MB-231 cells were exposed to $25 \mu \mathrm{g} / \mathrm{ml}$ of cycloheximide (CHX), an inhibitor of eukaryotic protein synthesis by preventing initiation and elongation on $80 \mathrm{~S}$ ribosomes [33], in the presence or absence of CPX (10 $\mu \mathrm{M}$ ) for up to $24 \mathrm{~h}$, followed by Western blot analysis. It turned out that CPX treatment strikingly promoted the protein turnover rate of $\mathrm{Cdc} 25 \mathrm{~A}$. As illustrated in

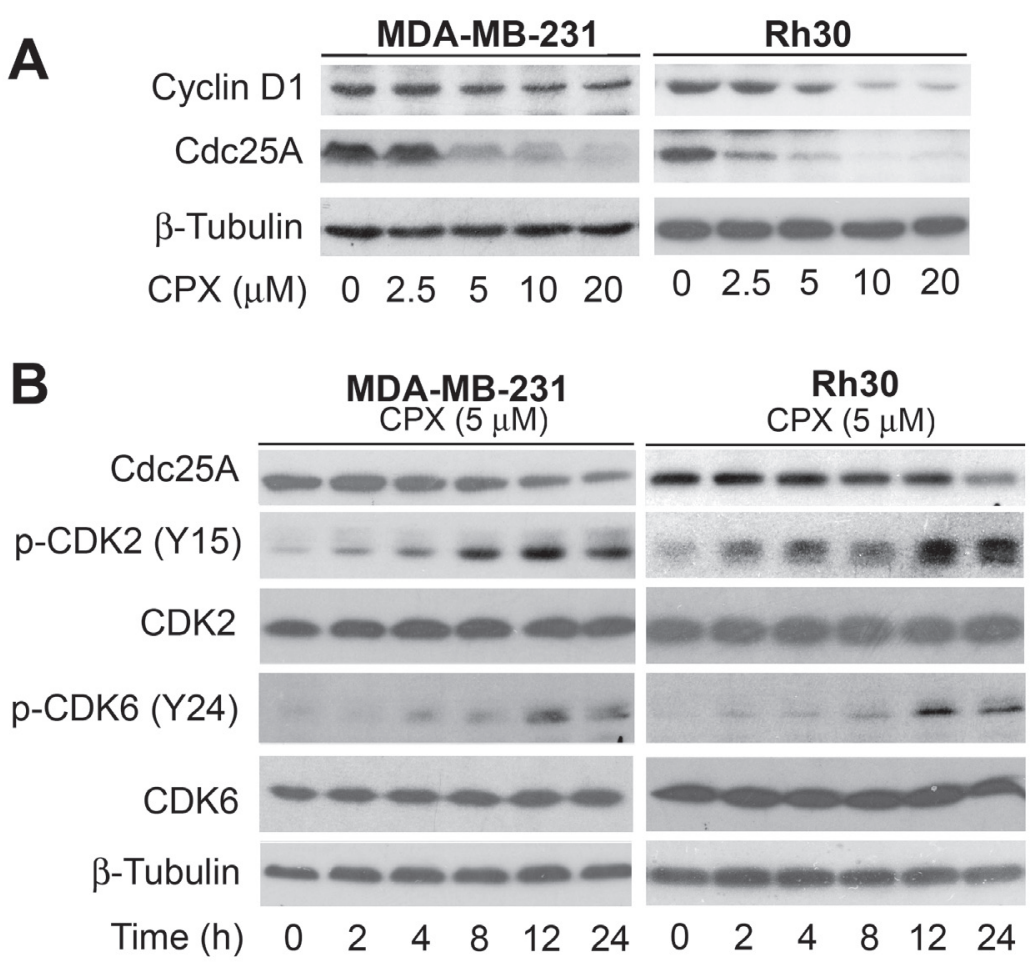

Figure 3: CPX downregulates the cellular protein level of Cdc25A, increasing the inhibitory phosphorylation level of CDK2 in tumor cells. (A) MDA-MB-231 and Rh30 cells were treated with CPX $(0-20 \mu \mathrm{M})$ for $24 \mathrm{~h}$ and $36 \mathrm{~h}$, respectively, followed by Western blotting with indicated antibodies. (B) Indicated cells were treated with $5 \mu \mathrm{M}$ of CPX for up to $24 \mathrm{~h}$, followed by Western blotting with indicated antibodies. 
Figure $4 \mathrm{C}$, approximately $50 \%$ of $\mathrm{Cdc} 25 \mathrm{~A}$ protein was still detectable when the cells were treated with $\mathrm{CHX}$ alone for $12 \mathrm{~h}$. However, about $50 \%$ of Cdc $25 \mathrm{~A}$ protein was observed when the cells were treated with $\mathrm{CHX}+$ CPX only for $4 \mathrm{~h}$. Taken together, our results indicate that CPX altered neither mRNA level nor protein synthesis of $\mathrm{Cdc} 25 \mathrm{~A}$, but promoted protein degradation of $\mathrm{Cdc} 25 \mathrm{~A}$, thereby downregulating cellular protein expression of Cdc25A in the tumor cells. Similar results were observed in Rh30 cells (Supplementary Figure S3C).

It is well known that the ubiquitin/proteasome pathway plays an important role in Cdc25A degradation [41-47]. To substantiate whether CPX-induced degradation of Cdc25A is through proteasome-dependent mechanism, MG132 (a proteasome inhibitor) was used. As expected, co-treatment with MG132 $(10 \mu \mathrm{M})$ did strongly prevent CPX from reducing the protein level of Cdc25A (see Supplementary Figure S4). The result support that CPX induced the protein degradation of Cdc25A indeed by ubiquitin-proteasome pathway.

\section{CPX-induced phosphorylation of Cdc25A links to its degradation}

As Cdc25A degradation is tightly associated with its phosphorylation [22, 23], next, we examined the phosphorylation status of Cdc25A. As shown in Figure 5A, treatment with CPX $(5 \mu \mathrm{M})$ for $0-24 \mathrm{~h}$ accumulated the phosphorylation on Cdc25A (S76 and S82) in Rh30 cells
A
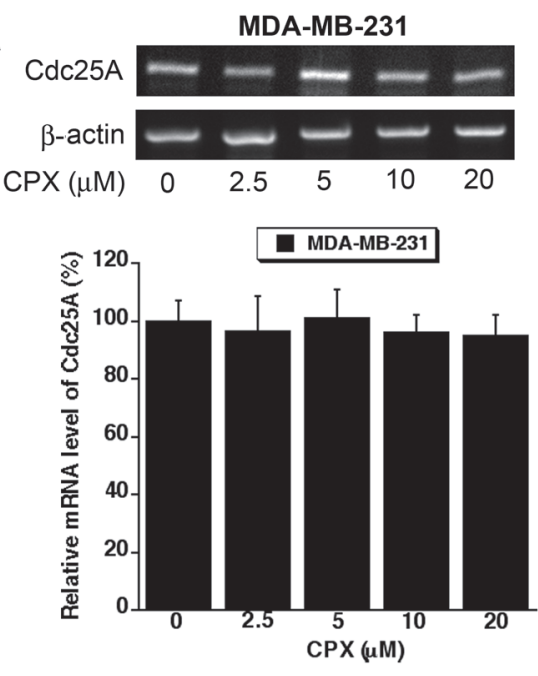

C

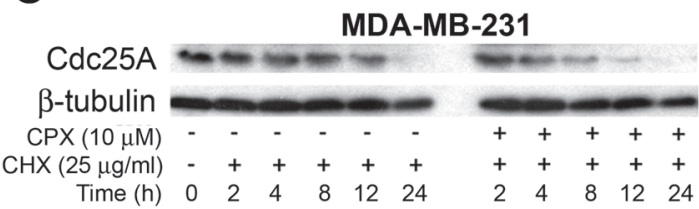

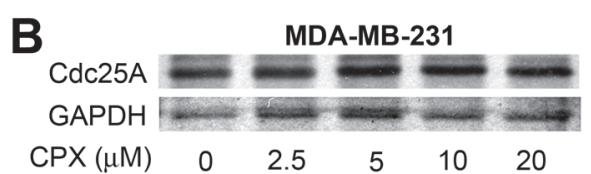
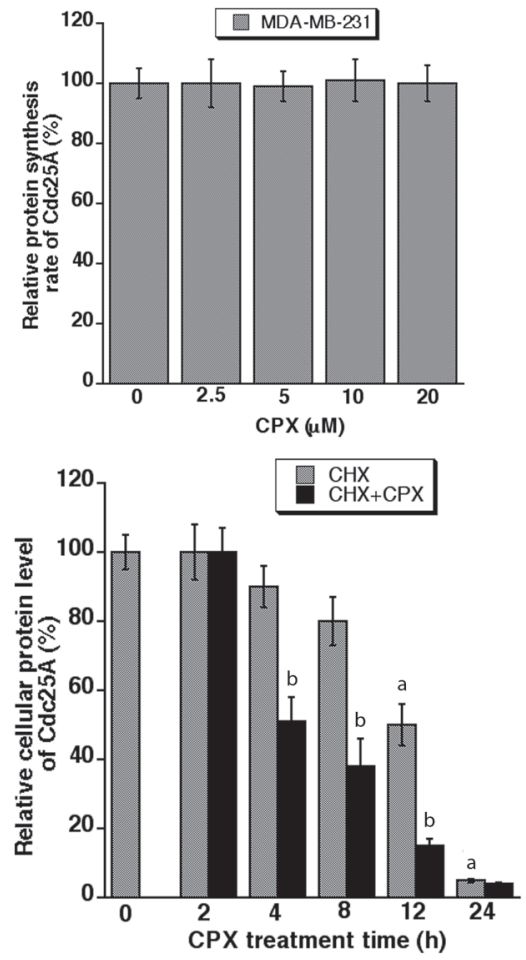

Figure 4: CPX does not reduce Cdc25A mRNA level or protein synthesis significantly, but promotes Cdc25A protein degradation markedly. (A) MDA-MB-231 cells were treated with CPX $(0-20 \mu \mathrm{M})$ for $24 \mathrm{~h}$. Total mRNA was extracted, followed by RT-PCR. $\beta$-actin was used as internal control. (B) MDA-MB-231 cells were treated with CPX at $0-20 \mu \mathrm{M}$ for $18 \mathrm{~h}$, and then pulsed with ${ }^{35} \mathrm{~S}-\mathrm{Met} / \mathrm{Cys}$ for $6 \mathrm{~h}$ in the presence of CPX $(0-20 \mu \mathrm{M})$. The proteins in the cell lysates were subjected to SDS-PAGE and transferred to a PVDF membrane, followed by autoradiography. GAPDH served as a control. (C) MDA-MB-231 cells were treated with $25 \mu \mathrm{g} / \mathrm{ml}$ cycloheximide (CHX), in the presence or absence of $10 \mu \mathrm{M} \mathrm{CPX}$, for $0-24 \mathrm{~h}$, followed by Western blotting with indicated antibodies. $\beta$-tubulin was used as a loading control. NIH Image J was used for semi-quantitative analysis of the intensities of the bands in (A-C). Results are means \pm SE and are pooled from three independent experiments. ${ }^{\mathrm{a}} P<0.05$, difference versus control group. ${ }^{\mathrm{b}} P<0.05$, difference versus $\mathrm{CHX}$ group. 
in a time-dependent manner. The cellular protein level of Cdc25A was reversely correlated to the phosphorylation status of Cdc25A. Similar data was observed in MDAMB-231 cells (Supplementary Figure S5A). The results suggest that CPX might induce the phosphorylation of Cdc25A, leading to the degradation of Cdc25A.

To corroborate whether CPX-induced phosphorylation of $\mathrm{Cdc} 25 \mathrm{~A}$ really contributes to its degradation, recombinant adenoviruses expressing GFP, wt or mutant Cdc25A (S76A or S82A) were generated and used to infect $\mathrm{Rh} 30$ cells. Of interest, infection with Ad-Cdc25A-wt, Ad-Cdc25A-S76A or Ad-Cdc25AS82A upregulated the Cdc25A protein levels by $1.5 \sim 1.8$ fold, compared to infection with Ad-GFP. Ectopic expression of Cdc25-S82A, but not GFP, Cdc25A-wt, or
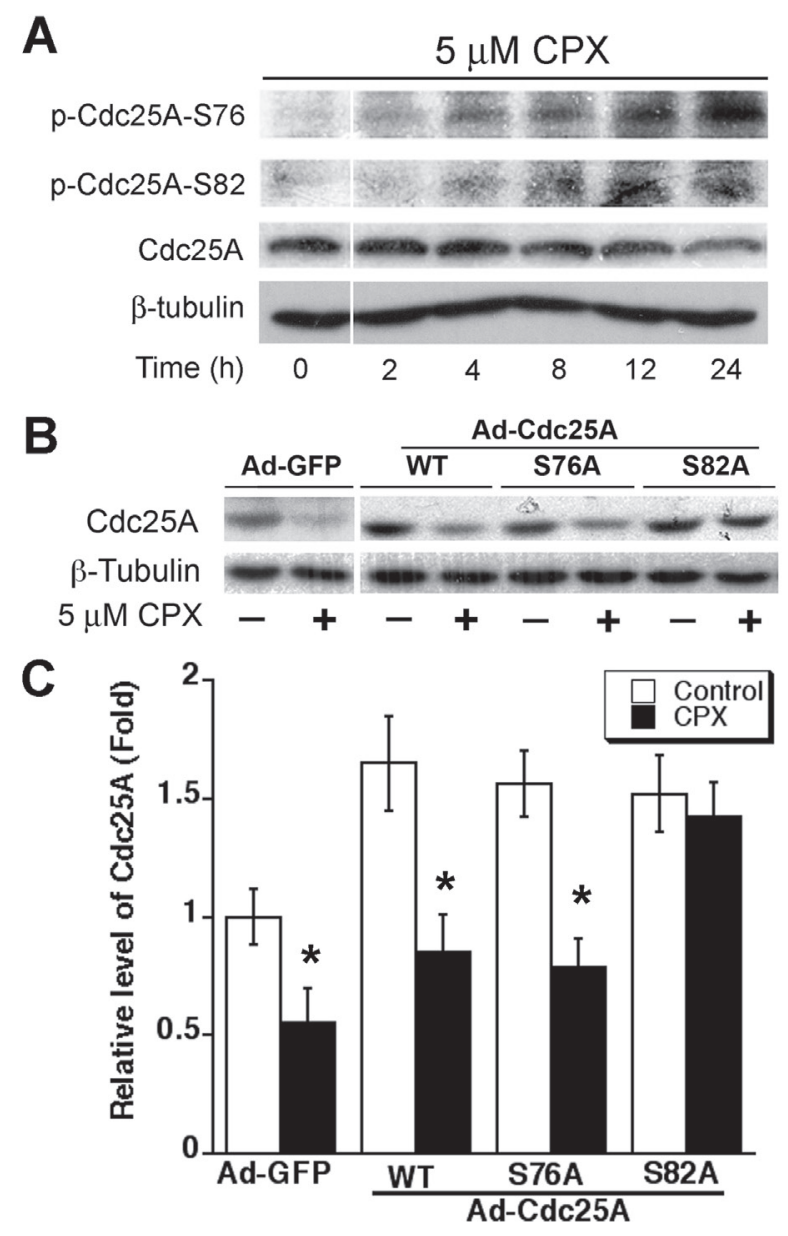

Figure 5: CPX-induced Cdc25A phosphorylation contributes to its degradation. (A) Rh30 cells were treated with CPX $(5 \mu \mathrm{M})$ for $0-24 \mathrm{~h}$, followed by Western blotting with indicated antibodies. (B) Rh30 cells, infected with indicated recombinant adenoviruses, were treated with or without CPX $(5 \mu \mathrm{M})$ for $24 \mathrm{~h}$, followed by Western blotting with indicated antibodies. $\beta$-tubulin was used as a loading control. (C) Semiquantitative analysis of the intensities of the bands in (B) using $\mathrm{NIH}$ Image J. All data represent the means $\pm \mathrm{SE}(\mathrm{n}=3) . * P<0.05$.
Cdc25A-S76A, conferred significant resistance to CPXinduced degradation of Cdc25A (Figures 5B and 5C). Similar results were observed in MDA-MB-231 cells (Supplementary Figure S5B). The results indicate that $\mathrm{CPX}$-induced degradation of $\mathrm{Cdc} 25 \mathrm{~A}$ is at least related to its induction of Cde25A phosphorylation on S82A.

\section{Ectopic expression of Cdc25A mutant (S82A) renders resistance to $\mathrm{CPX}$ inhibition of cell proliferation}

Since ectopic expression of Cdc25A-S82A mutant conferred high resistance to $\mathrm{CPX}$-induced degradation of Cdc25A (Figure 5B), we asked whether expression of this mutant affects CPX-induced CDK2 phosphorylation. Consistent with the above results (Figure 5), infection with Ad-Cdc25A-S82A or Ad-Cdc25A-wt upregulated the Cdc25A protein levels by $1.5 \sim 2$ fold, compared to infection with Ad-GFP. Treatment with CPX $(5 \mu \mathrm{M})$

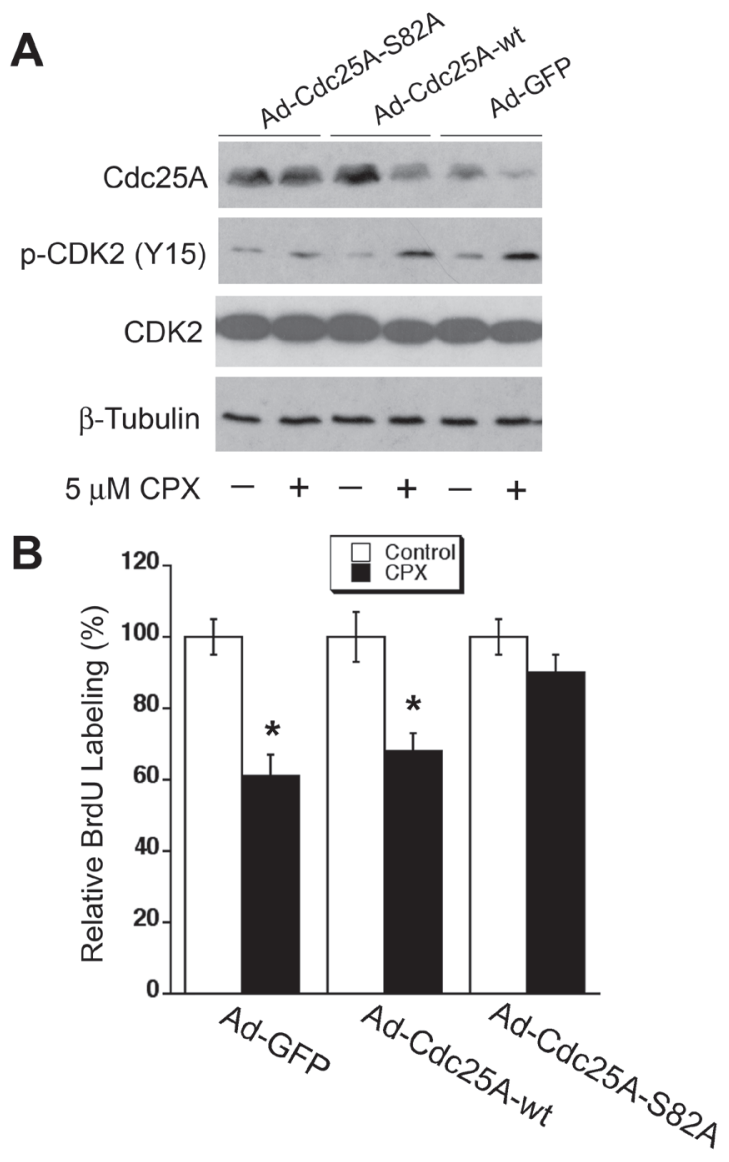

Figure 6: Ectopic expression of Cdc25A mutant (S82A) renders resistance to $\mathrm{CPX}$ inhibition of cell proliferation. (A, B) Rh30 cells, infected with indicated recombinant adenoviruses, were treated with $5 \mu \mathrm{M}$ of CPX for $36 \mathrm{~h}$, followed by Western blotting with indicated antibodies (A), and BrdU labeling (B). All data represent the means $\pm \mathrm{SE}$ $(\mathrm{n}=3) .{ }^{*} P<0.05$. 
reduced $\mathrm{Cdc} 25 \mathrm{~A}$ levels by approximately $50 \%$ in the cells infected with Ad-GFP or Ad-Cdc25A-wt, but did not apparently alter Cdc25A levels in the cells infected with Ad-Cdc25A-S82A. As expected, CPX increased the levels of p-CDK2 (Y15) in Ad-GFP or Ad-Cdc25Awt infected cells by about 2 -fold, but only very slightly in Ad-Cdc25A-S82A infected cells (Figure 6A). In line with this, ectopic expression of Cdc25A-S82A, but not GFP or Cdc25A-wt, also rendered cells resistant to CPXinduced inhibition of cell proliferation, as assessed by BrdU labeling (Figure 6B). Similar results were observed in MDA-MB-231 cells (see Supplementary Figure S6). Collectively, our results demonstrate that CPX inhibits cell proliferation by inducing the phosphorylation of $\mathrm{Cdc} 25 \mathrm{~A}$ on $\mathrm{S} 82$, leading to the degradation of $\mathrm{Cdc} 25 \mathrm{~A}$ and inhibition of CDK2.

\section{DISCUSSION}

CPX is an off-patent fungicide, which has been used to treat fungal infection of the skin and nails for more than 20 years [1]. Recent studies have demonstrated that CPX also possesses anti-proliferative activity in tumor cells [6, 7]. It has been described that CPX inhibits DNA synthesis by suppressing ribonucleotide reductase [6]. Also, $\mathrm{CPX}$, at high concentrations $(>10 \mu \mathrm{M})$, downregulates the cellular protein levels of cyclins (A, B1, D1 and E) and cyclin-dependent kinases (CDK2 and CDK4), and upregulates the protein level of the CDK inhibitor (p21 ${ }^{\text {Cipl }}$ ) [7]. Here, for the first time, we show that CPX, at low concentrations $(\leq 5 \mu \mathrm{M})$, also reduced the cellular protein level of Cdc25A, which resulted in increased inhibitory phosphorylation of $\mathrm{G}_{1}-\mathrm{CDKs}$, leading to the accumulation of cells in $\mathrm{G}_{1}$ phase of the cell cycle in breast carcinoma (MDA-MB-231) and rhabdomyosarcoma (Rh30) cells. Taken together, the findings from this group and others support the notion that CPX inhibits tumor cell proliferation by multiple mechanisms, and $\mathrm{Cdc} 25 \mathrm{~A}$ is one of the critical targets of CPX.

As Cdc25A is important for cell cycle progression, its activity has to be timely and precisely regulated during the whole cell cycle. This can be achieved by multiple mechanisms including the regulation of Cdc25A expression at transcriptional $[34,35]$, translational [36, 37], and/or post-translational levels [38], as well as the regulation of the catalytic efficiency of Cdc25A by modulating its phosphatase activity [36] and enzymesubstrate interaction [39, 40]. In this study, we found that CPX downregulated the cellular protein level of $\mathrm{Cdc} 25 \mathrm{~A}$ at the post-translational level. This is strongly supported by our results that CPX did not significantly reduce the mRNA level of Cdc25A or the protein synthesis rate of $\mathrm{Cdc} 25 \mathrm{~A}$, but remarkably promoted the protein degradation rate of $\mathrm{Cdc} 25 \mathrm{~A}$ in tumor cells (Figure 4 and Supplementary Figure S3). CPX-induced degradation of Cdc25A was proteasome-dependent, as treatment with
MG132, a proteasome inhibitor, almost dramatically blocked the reduction of $\mathrm{Cdc} 25 \mathrm{~A}$ protein level triggered by CPX (Supplementary Figure S4). In addition, we observed that $\mathrm{CPX}$-induced $\mathrm{Cdc} 25 \mathrm{~A}$ degradation was closely related to induction of $\mathrm{Cdc} 25 \mathrm{~A}$ phosphorylation on S82, as ectopic expression of the mutant Cdc25AS82A, but not Cdc25A-wt or Cdc25A-S76A, conferred high resistance to CPX-induced degradation of $\mathrm{Cdc} 25 \mathrm{~A}$ in Rh30 (Figure 5) and MDA-MB-231 cells (Supplementary Figure S5). Furthermore, we found that ectopic expression of Cdc25A-S82A rendered cells resistant to CPX-induced CDK2 phosphorylation (Y15) and cell proliferation inhibition in Rh30 (Figure 6) and MDA-MB-231 cells (Supplementary Figure S6).

A derived question from the current work is the identity of the kinase that phosphorylates Cdc25A, leading to its degradation. It has been described that Chk1 phosphorylates multiple residues on $\mathrm{Cdc} 25 \mathrm{~A}$, among which, phosphorylation on S76 is necessary for further phosphorylation on $\mathrm{S} 79$ and $\mathrm{S} 82$, residues locating in DSG motif (RMGS76SES79TDS82GFCLDS88PGPLD), by casein kinase 1 [41-46]. After phosphorylation at S82, an E3 ligases complex, SCF (Skp1/Cul1/F-box protein) binds to $\mathrm{Cdc} 25 \mathrm{~A}$ through interaction between DSG motif and $\beta$-TrCP (F-box protein) to facilitate Cdc25A ubiquitination and subsequent degradation $[41,47]$. In addition, both glycogen synthase kinase $3 \beta$ (GSK-3 $\beta$ ) and serine-threonine kinase 38 (STK38) can also phosphorylate $\mathrm{S} 76$ residue of $\mathrm{Cdc} 25 \mathrm{~A}[48,49]$. The GSK-3 $\beta$-induced phosphorylation on S76, which requires a prime phosphorylation on T80 by Polo-like kinase 3, is associated with SCF-mediated Cde25A degradation and G1/S cell cycle arrest [48]. Recent studies have further shown that serine/threonine protein kinase SMG1 mediates the degradation of Cdc25A by directly phosphorylating Cdc25A in a Chk1-independent manner [50], though a phosphorylation site has not been identified. In our study, we noticed co-treatment with GSK-3 $\beta$ inhibitor $(10 \mathrm{mM} \mathrm{LiCl})$ for $24 \mathrm{~h}$ did not prevent CPX from inducing Cdc25A degradation in MDA-MB-231 cells, suggesting that GSK-3 $\beta$ might not be the kinase that phosphorylates Cdc25A, leading to Cdc25A degradation, in response to CPX treatment. In addition, we found that although CPX induced the phosphorylation of both $\mathrm{S} 76$ and S82 (Figure 5A), CPX reduced the Cdc25A protein level in the cells expressing the S76A mutant, but not the S82A mutant (Figure 5B), further implying that the kinase that phosphorylates S82 may not require a prior phosphorylation on S76. Clearly, more studies are required to identify the CPX-activated kinase that phosphorylates Cdc25A.

In summary, here we have shown that treatment with CPX induced the phosphorylation of Cdc25A, which promoted the protein degradation of $\mathrm{Cdc} 25 \mathrm{~A}$ in rhabdomyosarcoma (Rh30) and breast cancer (MDAMB-231) cells. Downregulation of $\mathrm{Cdc} 25 \mathrm{~A}$ protein 
expression resulted in accumulation of the inhibitory phosphorylation of $\mathrm{G}_{1}-\mathrm{CDKs}$, thus interrupting the cell cycle progression. The findings provide a new insight into the molecular mechanism by which CPX inhibits CDKs related to cell proliferation.

\section{MATERIALS AND METHODS}

\section{Materials}

Ciclopirox olamine (CPX) (Sigma, St. Louis, MO, USA) was dissolved in $100 \%$ ethanol to prepare a stock solution $(100 \mathrm{mM})$, then aliquoted and stored at $-20^{\circ} \mathrm{C}$. RPMI 1640, Dulbecco's Modifid Eagle Medium (DMEM), and DMEM/F-12 were purchased from Mediatech (Herndon, VA, USA). Fetal bovine serum (FBS) was from Hyclone (Logan, UT) and 0.05\% TrypsinEDTA was from Invitrogen (Grand Island, NY, USA). 5-bromo-2-deoxyuridine (BrdU) and 4',6-diamidino-2phenylindole (DAPI) were from Life Technologies (Grand Island, NY, USA). Enhanced chemiluminescence solution was obtained from PerkinElmer Life Science (Boston, MA, USA). The following primary antibodies were used, including those against BrdU (Cat.\# sc-32323), cyclin D1 (Cat.\# sc-20044), CDK6 (Cat.\# sc-56282), p-CDK6 (Y24) (Cat.\# sc-293097), CDK2 (Cat.\# sc-6248), Cdc25A (Cat.\# sc-97), GAPDH (Cat.\# sc-32233) (Santa Cruz Biotechnology, Santa Cruz, CA, USA), p-CDK2 (Y15) (Cat.\# ab76146), p-Cdc25A (S76) (Cat.\# ab75743) (Abcam, Cambridge, MA, USA), p-Cdc25A (S82) (a gift from Dr. Helen Piwnica-Worms, Washington University School of Medicine, St. Louis, MO) [43], and $\beta$-tubulin (Cat.\# T4026) (Sigma, St. Louis, MO, USA). Goat antimouse IgG-horseradish peroxidase (Cat.\# 31430) and goat anti-rabbit IgG-horseradish peroxidase (Cat.\# 31460) were purchased from Pierce (Rockford, IL, USA). All other reagents were obtained from Sigma-Aldrich (St. Louis, MO, USA) unless otherwise specified.

\section{Cell lines and cultures}

Human rhabdomyosarcoma (Rh30 and RD) cells were generously provided by Dr. Peter J. Houghton (St. Jude Children's Research Hospital, Memphis, TN, USA), and were grown in antibiotic-free RPMI 1640 medium supplemented with $10 \%$ FBS. Human breast carcinoma (MDA-MB-231 and MCF7), colorectal adenocarcinoma (HT29), and lung carcinoma (A549) cells were purchased from American Type Culture Collection (Manassas, VA, USA). MDA-MB-231 and MCF7 cells were grown in antibiotic-free DMEM/F12 supplemented with $10 \%$ FBS, while HT29 and A549 were cultured in antibioticfree DMEM supplemented with 10\% FBS. All cell lines were cultured in a humidified incubator $\left(37^{\circ} \mathrm{C}\right.$ and $5 \% \mathrm{CO}_{2}$ ). In all treatments, $\mathrm{CPX}$ was dissolved in $100 \%$ ethanol to prepare a stock solution $(100 \mathrm{mM})$. The subconfluent cells (60-70\% confluent) were treated with various concentrations of CPX in the complete cell culture medium. Cells treated with vehicle (ethanol, final concentration in media $=0.1 \%$ ) served as a control.

\section{Recombinant adenoviral constructs and infection}

To generate recombinant adenoviruses expressing Cdc25A-wild type (wt) or mutants, DNA encoding wt or mutant Cdc25A (S76A or S82A) was, respectively, excised from pCDNA4/TO-Cdc25A-wt, S76A, or S82A [51] (gifts from Dr. Xianghong Zou, Ohio State University, Columbus, OH, USA) using BamH1 and EcoR1. The recombinant adenoviruses and the control virus expressing green fluorescence protein (GFP) were generated and amplified using ViraPower ${ }^{\mathrm{TM}}$ Adenoviral Gateway ${ }^{\mathrm{TM}}$ Expression Kit (Invitrogen, Carlsbad, CA, USA) following the manufacture's instruction. All adenoviruses were amplified, titrated and used as described previously $[52,53]$.

\section{Cell proliferation assay}

Cell proliferation was evaluated using either CellTiter $96^{\circledR} \mathrm{AQ}_{\text {ueous }}$ One Solution Cell Proliferation Assay kit (Promega, Madison, WI, USA) or direct cell counting using a Beckman Coulter Counter (Beckman Coulter, Fullerton, CA, USA), as described previously [7].

\section{BrdU labeling}

Rh30 cells, infected with Ad-GFP, Ad-Cdc25A-wt, -S76A, or -S82A, were plated on the coverslips in 6-well plates. The next day, the cells were treated with or without $5 \mu \mathrm{M}$ of CPX for $24 \mathrm{~h}$, followed by labeling with $3 \mu \mathrm{g} /$ $\mathrm{ml}$ of $\mathrm{BrdU}$ for $3 \mathrm{~h}$ at $37^{\circ} \mathrm{C}$. The cells were then fixed with cold $70 \%$ ethanol for $10 \mathrm{~min}$ at room temperature, rinsed 3 times with phosphate buffered saline (PBS), and treated with $2 \mathrm{~N} \mathrm{HCl}$ for $30 \mathrm{~min}$ at room temperature to denature DNA. Next, the cells were rinsed 3 times with PBS, and incubated with 5\% normal horse serum (diluted in PBS containing $0.2 \%$ Triton $\mathrm{X}-100$ ) for $1 \mathrm{~h}$ at room temperature to block nonspecific epitopes. Afterwards, the cells were incubated with mouse monoclonal antiBrdU antibody overnight at $4^{\circ} \mathrm{C}$. Following rinsing 3 times with PBS, the cells were further incubated with goat anti-mouse IgG conjugated with Texas Red (Santa Cruz Biotechnology, Santa Cruz, CA, USA) for $1 \mathrm{~h}$ at room temperature in dark. The cells were rinsed 3 times with PBS, and then further stained with $1 \mu \mathrm{g} / \mathrm{ml}$ DAPI (dissolved in Milli $\mathrm{H}_{2} \mathrm{O}$ ) for 3 min at room temperature. Following a brief washing with PBS, slides were 
mounted in glycerol/PBS (1:1, v/v) containing 2.5\% 1,4-diazabiclo-(2,2,2)octane. Photographs for BrdU (red) and DAPI (blue) staining were taken under a Nikon Eclipse TE300 fluorescence microscope equipped with a digital camera. The proliferation index was determined by measuring the percentage of BrdU positive cells. At least 500 cells were counted.

\section{Cell cycle analysis}

Cell cycle analysis was performed, as described previously [7]. Briefly, Rh30 or MDA-MB-231 cells were treated with CPX at $5 \mu \mathrm{M}$ for $0-72 \mathrm{~h}$, followed by staining with the Cellular DNA Flow Cytometric Analysis Kit (Roche Diagnostics, Indianapolis, IN, USA). Percentages of cells within each of the cell cycle compartments $\left(\mathrm{G}_{0} /\right.$ $\mathrm{G}_{1}, \mathrm{~S}$, or $\mathrm{G}_{2} / \mathrm{M}$ ) were determined using a FACSCalibur flow cytometer (Becton Dickinson, Mountain View, CA, USA) and ModFit LT analyzing software (Verity Software House, Topsham, ME, USA). Cells treated with vehicle alone (100\% ethanol) were used as a control.

\section{Reverse transcription-polymerase chain reaction (RT-PCR) analysis for Cdc25A mRNA expression}

Total mRNA was extracted from Rh30 or MDAMB-231 cells, after treatment with CPX (0-20 $\mu \mathrm{M})$ for $24 \mathrm{~h}$, using TRIzol reagent (Invitrogen) following the manufacturer's instruction. cDNA was made using MML-VII reverse transcriptase (Invitrogen) and oligo $(\mathrm{dT})_{12-18}$ primer (Invitrogen). PCR was performed using 10 ng cDNA, Taq DNA polymerase (New England Biolabs, Ipswich, MA, USA) and specific primer pairs for $\operatorname{Cdc} 25 \mathrm{~A}$ and $\beta$-actin (as internal control), respectively. The forward primer for $\mathrm{Cdc} 25 \mathrm{~A}$ is: 5'-atggaactgggeccggag- $3^{\prime}$; and the backward primer is: $5^{\prime}$-agtggctgtcacaggtgact-3'; the forward primer for $\beta$-actin is: $\quad$ '-TACGGGGTCACCCACACTGTGCCCAT-3; and the backward primer is: 5'-CTAGAAGCATTTGCGGTGGACGATGGAGGG-3'. The amplification was done for 30 cycles $\left(94^{\circ} \mathrm{C} 30 \mathrm{~s}\right.$, $62^{\circ} \mathrm{C} 30 \mathrm{~s}$ and $72^{\circ} \mathrm{C} 40 \mathrm{~s}$ ). PCR products were size fractionated on $2 \%$ agarose gels and photographed on a UV transilluminator equipped with a digital camera. NIH Image J (https://imagej.nih.gov/ij/) was used for semiquantitative analysis of the intensities of the bands.

\section{${ }^{35} \mathrm{~S}-M e t / C y s$ labeling for $\mathrm{Cdc} 25 \mathrm{~A}$ protein synthesis}

${ }^{35} \mathrm{~S}-\mathrm{Met} / \mathrm{Cys}$ labeling was performed, as described previously [54]. Briefly, Rh30 or MDA-MB-231 cells, grown in $100-\mathrm{mm}$ dishes to $70 \%$ confluence, were treated with CPX $(0-20 \mu \mathrm{M})$ for $30 \mathrm{~h}$ or $18 \mathrm{~h}$, respectively. Subsequently, the cells were briefly washed with PBS twice, and cultured in $3 \mathrm{ml}$ labeling medium (DMEM, without L-Met/L-Cys, Mediatech, Herndon, VA, USA) containing $10 \mu \mathrm{M}$ MG-132 for $10 \mathrm{~min}$ to deplete Met/ Cys in the cells, in the presence of CPX (0-20 $\mu \mathrm{M})$. The cells were then pulsed with $0.3 \mathrm{mCi}{ }^{35} \mathrm{~S}-\mathrm{Met} / \mathrm{Cys}$ (MP Biomedicals, Solon, OH, USA) for $6 \mathrm{~h}$ in the presence of CPX $(0-20 \mu \mathrm{M})$, and lysed in the RIPA buffer [50 mM Tris, $\mathrm{pH} 7.2 ; 150 \mathrm{mM} \mathrm{NaCl} ; 1 \%$ sodium deoxycholate; $0.1 \%$ SDS; $1 \%$ Triton-X 100; $10 \mathrm{mM} \mathrm{NaF;} 1 \mathrm{mM}$ $\mathrm{Na}_{3} \mathrm{VO}_{4}$; protease inhibitor cocktail (1:1000, Sigma, St. Louis, MO, USA)], followed by immunoprecipitation with antibodies to $\mathrm{Cdc} 25 \mathrm{~A}$ and GAPDH, respectively. The immunocomplexes were subjected to SDSPAGE, transferred to a PVDF membrane, and finally autoradiographed at $-80^{\circ} \mathrm{C}$. NIH Image $\mathrm{J}$ was used for semi-quantitative analysis of the intensities of the bands.

\section{Cdc25A protein degradation assay}

To determine the effect of CPX on Cdc25A protein degradation, Rh30 or MDA-MB-231 cells, grown in the growth medium to $70 \%$ confluence, were treated with cycloheximide (CHX) (25 $\mu \mathrm{g} / \mathrm{ml}$ for MDA-MB-231 cells, and $50 \mu \mathrm{g} / \mathrm{ml}$ for Rh30 cells), in the presence or absence of CPX $(10 \mu \mathrm{M})$, for $0-24 \mathrm{~h}$, followed by Western blotting with antibodies to $\mathrm{Cdc} 25 \mathrm{~A}$ and $\beta$-tubulin (loading control), respectively. NIH Image $\mathrm{J}$ was used for semi-quantitative analysis of the intensities of the bands.

\section{Western blotting}

Western blotting was performed as described previously [7]. NIH Image $\mathrm{J}$ was used for semiquantitative analysis of the intensities of the bands.

\section{Statistical analysis}

Results were expressed as mean values \pm standard error (mean $\pm \mathrm{SE}$ ). The data were analyzed by one-way analysis of variance (ANOVA) followed by post-hoc Dunnett's $t$-test for multiple comparisons. A level of $P<$ 0.05 was considered to be statistically significant.

\section{ACKNOWLEDGMENTS}

We are grateful for Drs. Helen Piwnica-Worms for generously providing p-Cdc25A (S82) antibody, Xianghong Zou for Cdc25A constructs, and Peter J. Houghton for Rh30 and RD cells.

\section{CONFLICTS OF INTEREST}

No conflicts of interest were disclosed. 


\section{GRANT SUPPORT}

This work was supported in part by National Institutes of Health (CA115414; S. Huang), American Cancer Society (RSG-08-135-01-CNE; S. Huang), and Carroll Feist Predoctoral Fellowship Awards (T. Shen and C. Shang), Feist-Weiller Cancer Center, Louisiana State University Health Sciences Center in Shreveport, LA.

\section{ABBREVIATIONS}

BrdU, 5-bromo-2-deoxyuridine; Cdc25, cell division cycle 25; CDK, cyclin dependent kinase; CPX, ciclopirox olamine; DAPI, 4',6-diamidino-2-phenylindole; DMEM, Dulbecco's Modifid Eagle Medium; FBS, Fetal bovine serum; GFP, green fluorescence protein; GSK-3 $\beta$, glycogen synthase kinase $3 \beta$; PBS, phosphate buffered saline; RT-PCR, reverse transcription-polymerase chain reaction.

\section{REFERENCES}

1. Subissi A, Monti D, Togni G, Mailland F. Ciclopirox: recent nonclinical and clinical data relevant to its use as a topical antimycotic agent. Drugs. 2010; 70: 2133-52.

2. Farinelli SE, Greene LA. Cell cycle blockers mimosine, ciclopirox, and deferoxamine prevent the death of PC12 cells and postmitotic sympathetic neurons after removal of trophic support. J Neurosci. 1996; 16: 1150-62.

3. Hoffman BD, Hanauske-Abel HM, Flint A, Lalande M. A new class of reversible cell cycle inhibitors. Cytometry. 1991; 12: 26-32.

4. Alpermann HG, Schutz E. Studies on the pharmacology and toxicology of ciclopiroxolamine. Arzneimittelforschung. 1981; 31: 1328-32.

5. Kellner HM, Arnold C, Christ OE, Eckert HG, Herok J, Hornke I, Rupp W. Pharmacokinetics and biotransformation of the antimycotic drug ciclopiroxolamine in animals and man after topical and systemic administration. Arzneimittelforschung. 1981; 31: 1337-53.

6. Eberhard Y, McDermott SP, Wang X, Gronda M, Venugopal A, Wood TE, Hurren R, Datti A, Batey RA, Wrana J, Antholine WE, Dick JE, Schimmer AD. Chelation of intracellular iron with the antifungal agent ciclopirox olamine induces cell death in leukemia and myeloma cells. Blood. 2009; 114: 3064-73.

7. Zhou H, Shen T, Luo Y, Liu L, Chen W, Xu B, Han X, Pang J, Rivera CA, Huang S. The antitumor activity of the fungicide ciclopirox. Int J Cancer. 2010; 127: 2467-77.

8. Weir SJ, Patton L, Castle K, Rajewski L, Kasper J, Schimmer AD. The repositioning of the anti-fungal agent ciclopirox olamine as a novel therapeutic agent for the treatment of haematologic malignancy. J Clin Pharm Ther. $2011 ; 36: 128-34$
9. Kim Y, Schmidt M, Endo T, Lu D, Carson D, SchmidtWolf IG. Targeting the Wnt/beta-catenin pathway with the antifungal agent ciclopirox olamine in a murine myeloma model. In Vivo. 2011; 25: 887-93.

10. Song S, Christova T, Perusini S, Alizadeh S, Bao RY, Miller BW, Hurren R, Jitkova Y, Gronda M, Isaac M, Joseph B, Subramaniam R, Aman A, et al. Wnt inhibitor screen reveals iron dependence of $\beta$-catenin signaling in cancers. Cancer Res. 2011; 71: 7628-39.

11. Ma TC, Langley B, Ko B, Wei N, Gazaryan IG, Zareen N, Yamashiro DJ, Willis DE, Ratan RR. A screen for inducers of $\mathrm{p} 21 \mathrm{waf} 1 / \mathrm{cip} 1$ identifies HIF prolyl hydroxylase inhibitors as neuroprotective agents with antitumor properties. Neurobiol Dis. 2013; 49: 13-21.

12. Sen S, Hassane DC, Corbett C, Becker MW, Jordan CT, Guzman ML. Novel mTOR inhibitory activity of ciclopirox enhances parthenolide antileukemia activity. Exp Hematol. 2013; 41: 799-807.

13. Mémin E, Hoque M, Jain MR, Heller DS, Li H, Cracchiolo B, Hanauske-Abel HM, Pe'ery T, Mathews MB. Blocking eIF5A modification in cervical cancer cells alters the expression of cancer-related genes and suppresses cell proliferation. Cancer Res. 2014; 74: 552-62.

14. Zhou H, Shen T, Shang C, Luo Y, Liu L, Yan J, Li Y, Huang S. Ciclopirox induces autophagy through reactive oxygen species-mediated activation of JNK signaling pathway. Oncotarget. 2014; 5: 10140-50.

15. Sidarovich V, Adami V, Gatto P, Greco V, Tebaldi T, Tonini GP, Quattrone A. Translational downregulation of HSP90 expression by iron chelators in neuroblastoma cells. Mol Pharmacol. 2015; 87: 513-24.

16. Zhou H, Shang C, Wang M, Shen T, Kong L, Yu C, Ye Z, Luo Y, Liu L, Li Y, Huang S. Ciclopirox olamine inhibits mTORC1 signaling by activation of AMPK. Biochem Pharmacol. 2016; 116: 39-50.

17. Minden MD, Hogge DE, Weir SJ, Kasper J, Webster DA, Patton L, Jitkova Y, Hurren R, Gronda M, Goard CA, Rajewski LG, Haslam JL, Heppert KE, et al. Oral ciclopirox olamine displays biological activity in a phase I study in patients with advanced hematologic malignancies. Am J Hematol. 2014; 89: 363-8.

18. Clement PM, Hanauske-Abel HM, Wolff EC, Kleinman HK, Park MH. The antifungal drug ciclopirox inhibits deoxyhypusine and proline hydroxylation, endothelial cell growth and angiogenesis in vitro. Int J Cancer. 2002; 100: 491-8.

19. Luo Y, Zhou H, Liu L, Shen T, Chen W, Xu B, Han X, Zhang F, Scott RS, Alexander JS, Alam A, Huang S. The fungicide ciclopirox inhibits lymphatic endothelial cell tube formation by suppressing VEGFR-3-mediated ERK signaling pathway. Oncogene. 2011; 30: 2098-107.

20. Malumbres M, Barbacid M. Cell cycle, CDKs and cancer: a changing paradigm. Nature Rev Cancer. 2009; 9: 153-66.

21. Sherr CJ, Beach D, Shapiro GI. Targeting CDK4 and 
CDK6: From Discovery to Therapy. Cancer Discov. 2016; 6: 353-67.

22. Boutros R, Lobjois V, Ducommun B. Cdc25 phosphatases in cancer cells: key players? Good targets? Nat Rev Cancer. 2007; 7: 495-507.

23. Rudolph J. Inhibiting transient protein-protein interactions: lessons from the $\mathrm{Cdc} 25$ protein tyrosine phosphatases. Nat Rev Cancer. 2007; 7: 202-11.

24. Sert V, Cans C, Tasca C, Bret-Bennis L, Oswald E, Ducommun B, De Rycke J. The bacterial cytolethal distending toxin (CDT) triggers a G2 cell cycle checkpoint in mammalian cells without preliminary induction of DNA strand breaks. Oncogene. 1999; 18: 6296-304.

25. Darbon JM, Penary M, Escalas N, Casagrande F, GoubinGramatica F, Baudouin C, Ducommun B. Distinct Chk2 activation pathways are triggered by genistein and DNAdamaging agents in human melanoma cells. J Biol Chem. 2000; 275: 15363-69.

26. Terada Y, Tatsuka M, Jinno S, Okayama H. Requirement for tyrosine phosphorylation of CDK4 in G1 arrest induced by ultraviolet irradiation. Nature. 1995; 376: 358-62.

27. Iavarone A, Massagué J. Repression of the CDK activator Cdc25A and cell-cycle arrest by cytokine TGF-beta in cells lacking the CDK inhibitor p15. Nature. 1997; 387: 417-22.

28. Saha P, Eichbaum Q, Silberman ED, Mayer BJ, Dutta A. p21CIP1 and Cdc25A: competition between an inhibitor and an activator of cyclin-dependent kinases. Mol Cell Biol. 1997; 17: 4338-45.

29. Gautier J, Solomon MJ, Booher RN, Bazan JF, Kirschner MW. Cdc25 is a specific tyrosine phosphatase that directly activates p34cdc2. Cell. 1991; 67: 197-211.

30. Olivier M, Eeles R, Hollstein M, Khan MA, Harris CC, Hainaut P. The IARC TP53 database: new online mutation analysis and recommendations to users. Hum Mutat. 2002; 19: 607-14.

31. Huang S, Liu LN, Hosoi H, Dilling MB, Shikata T, Houghton PJ. p53/p21CIP1 cooperate in enforcing rapamycin-induced G1 arrest and determine the cellular response to rapamycin. Cancer Res. 2001; 61: 3373-81.

32. Odaka Y, Xu B, Luo Y, Shen T, Shang C, Wu Y, Zhou H, Huang S. Dihydroartemisinin inhibits the mammalian target of rapamycin-mediated signaling pathways in tumor cells. Carcinogenesis. 2014; 35: 192-200.

33. Pestova TV, Hellen CU. Translation elongation after assembly of ribosomes on the Cricket paralysis virus internal ribosomal entry site without initiation factors or initiator tRNA. Genes Dev. 2003; 17: 181-6.

34. Vigo E, Müller H, Prosperini E, Hateboer G, Cartwright P, Moroni MC, Helin K. CDC25A phosphatase is a target of $\mathrm{E} 2 \mathrm{~F}$ and is required for efficient E2F-induced S phase. Mol Cell Biol. 1999; 19: 6379-95.

35. Galaktionov K, Chen X, Beach D. Cdc25 cell-cycle phosphatase as a target of c-myc. Nature. 1996; 382: 511-7.

36. Lin YM, Chung CL, Cheng YS. Posttranscriptional regulation of CDC25A by BOLL is a conserved fertility mechanism essential for human spermatogenesis. J Clin Endocrinol Metab. 2009; 94: 2650-7.

37. Tomko RJ Jr., Lazo JS. Multimodal control of Cdc25A by nitrosative stress. Cancer Res. 2008; 68: 7457-65.

38. Busino L, Chiesa M, Draetta G, Donzelli M. Cdc25A phosphatase: combinatorial phosphorylation, ubiquitylation and proteolysis. Oncogene. 2004; 23: 2050-6.

39. Chen M-S, Ryan CE, Piwnica-Worms H. Chk1 kinase negatively regulates mitotic function of $\mathrm{Cdc} 25 \mathrm{~A}$ phosphatase through 14-3-3 binding. Mol Cell Biol. 2003; 23: 7488-97.

40. Uto K, Inoue D, Shimuta K, Nakajo N, Sagata N. Chk1, but not Chk2, inhibits Cdc25 phosphatases by a novel common mechanism. EMBO J. 2004; 23: 3386-96.

41. Sørensen CS, Syljuåsen RG, Falck J, Schroeder T, Rönnstrand L, Khanna KK, Zhou BB, Bartek J, Lukas J. Chk1 regulates the $\mathrm{S}$ phase checkpoint by coupling the physiological turnover and ionizing radiation-induced accelerated proteolysis of Cdc25A. Cancer Cell. 2003; 3: 247-58.

42. Jin J, Ang XL, Ye X, Livingstone M, Harper JW. Differential roles for checkpoint kinases in DNA damagedependent degradation of the Cdc25A protein phosphatase. J Biol Chem. 2008; 283: 19322-8.

43. Honaker Y, Piwnica-Worms H. Casein kinase 1 functions as both penultimate and ultimate kinase in regulating $\mathrm{Cdc} 25 \mathrm{~A}$ destruction. Oncogene. 2010; 29: 3324-34.

44. Hassepass I, Voit R, Hoffmann I. Phosphorylation at serine 75 is required for UV-mediated degradation of human Cdc25A phosphatase at the S-phase checkpoint. J Biol Chem. 2003; 278: 29824-9.

45. Piao S, Lee SJ, Xu Y, Gwak J, Oh S, Park BJ, Ha NC. CK1\& targets Cdc25A for ubiquitin-mediated proteolysis under normal conditions and in response to checkpoint activation. Cell Cycle. 2011; 10: 531-7.

46. Donzelli M, Busino L, Chiesa M, Ganoth D, Hershko A, Draetta GF. Hierarchical order of phosphorylation events commits Cdc25A to beta TrCP-dependent degradation. Cell Cycle. 2004; 3: 469-71.

47. Busino L, Donzelli M, Chiesa M, Guardavaccaro D, Ganoth D, Dorrello NV, Hershko A, Pagano M, Draetta GF. Degradation of Cdc25A by beta-TrCP during S phase and in response to DNA damage. Nature. 2003; 426: 87-91.

48. Kang T, Wei Y, Honaker Y, Yamaguchi H, Appella E, Hung MC, Piwnica-Worms H. GSK-3 $\beta$ targets Cdc25A for ubiquitin-mediated proteolysis, and GSK-3 $\beta$ inactivation correlates with Cdc25A overproduction in human cancers. Cancer Cell. 2008; 13: 36-47.

49. Fukasawa T, Enomoto A, Miyagawa K. Serine-Threonine Kinase 38 regulates CDC25A stability and the DNA damage-induced G2/M checkpoint. Cell Signal. 2015; 27 : 1569-75.

50. Gubanova E, Issaeva N, Gokturk C, Djureinovic T, 
Helleday T. SMG-1 suppresses CDK2 and tumor growth by regulating both the $\mathrm{p} 53$ and $\mathrm{Cdc} 25 \mathrm{~A}$ signaling pathways. Cell Cycle. 2013; 12: 3770-80.

51. Wu Y, Feng X, Jin Y, Wu Z, Hankey W, Paisie C, Li L, Liu F, Barsky SH, Zhang W, Ganju R, Zou X. A novel mechanism of indole-3-carbinol effects on breast carcinogenesis involves induction of Cdc25A degradation. Cancer Prev Res (Phila). 2010; 3: 818-28.

52. Luo Y, Liu L, Wu Y, Singh K, Su B, Zhang N, Liu X, Shen $\mathrm{Y}$, Huang S. Rapamycin inhibits $\mathrm{mSin} 1$ phosphorylation independently of mTORC1 and mTORC2. Oncotarget. 2015; 6: 4286-98.

53. Chen L, Xu B, Liu L, Liu C, Luo Y, Chen X, Barzegar M, Chung J, Huang S. Both mTORC1 and mTORC2 are involved in the regulation of cell adhesion. Oncotarget. 2015; 6: 7136-50.

54. Luo Y, Liu L, Rogers D, Su W, Odaka Y, Zhou H, Chen W, Shen T, Alexander JS, Huang S. Rapamycin inhibits lymphatic endothelial cell tube formation by downregulating vascular endothelial growth factor receptor 3 protein expression. Neoplasia. 2012; 14: 228-37. 